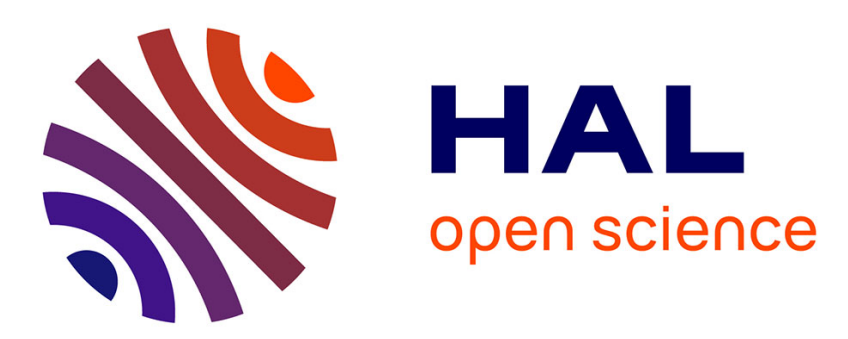

\title{
ANOMALOUS 57Fem CHARGE STATES IN COMPLEXES OXIDES
}

J. Tejada, X. Obradors, J. Fontcuberta, J. Rodriguez, R. Rodriguez, M. Oliva

\section{To cite this version:}

J. Tejada, X. Obradors, J. Fontcuberta, J. Rodriguez, R. Rodriguez, et al.. ANOMALOUS 57Fem CHARGE STATES IN COMPLEXES OXIDES. Journal de Physique Colloques, 1980, 41 (C1), pp.C1461-C1-462. 10.1051/jphyscol:19801181 . jpa-00219670

\section{HAL Id: jpa-00219670 https://hal.science/jpa-00219670}

Submitted on 1 Jan 1980

HAL is a multi-disciplinary open access archive for the deposit and dissemination of scientific research documents, whether they are published or not. The documents may come from teaching and research institutions in France or abroad, or from public or private research centers.
L'archive ouverte pluridisciplinaire HAL, est destinée au dépôt et à la diffusion de documents scientifiques de niveau recherche, publiés ou non, émanant des établissements d'enseignement et de recherche français ou étrangers, des laboratoires publics ou privés. 
ANOMALOUS ${ }^{57} \mathrm{Fe}^{\mathrm{m}}$ CHARGE STATES IN COMPLEXES OXIDES

J. Tejada, X. Obradors, J. Fontcuberta, J. Rodriguez ${ }^{+}$, R. Rodriguez ${ }^{+}$and M. Oliva

Facultad Fisica. Universidad de Barcelona. Diagonal 645. Barcelona 28. Spain .

+ Facultad de Geologia. Universidad de Barcelona. Avda. José Antonio 585, Barcelona 7. Spain .

Abstract

Mussbauer measurements on non-stoichiometric spinels ( $\mathrm{CoRh}_{2} \mathrm{O}_{4+x}, \mathrm{CoMn}_{2} \mathrm{O}_{4+x}$ ) and oxygen deficient oxides with perovskites and perovskite related structures ( $\mathrm{LnCaO}_{3-x}$ with $\mathrm{L}_{n}=\mathrm{Eu}, \mathrm{La}, \mathrm{DY}, \mathrm{Y}$ and $\left.\mathrm{LaCoO}_{3}: \mathrm{Sr}^{2+}\left(\mathrm{Ca}^{2+}\right)\right)$ dopped with ${ }^{57} \mathrm{Co}$ have been done. It is argued that the charge states of the ${ }^{57} \mathrm{Fe}^{\mathrm{m}}$ daughter depend on the nature and concentration of vacancies present in the lattice. In perovskites the existence of vacancies both random and of ordered distribution has been observed.

\section{Introduction}

The investigation by means of Mussbauer spectroscopy of non stoichiometry in single phases perovskites and spinels is of interest, because the existence of mixed valence states for the Mussbauer cations can be determined(1). The existence of cationic (spinels) or anionic (perovskites) vacancies, with variable concentration, is related to more distorted local structures (2). The present study is concerned with further investigation (3) about the consequences of electronic capture in oxides.

Experimental

Specimens were prepared from appropiate mixtures of highly pure nitrates (for spinels) or oxides (for perovskites) dopped with ${ }^{57} \mathrm{CoCl}_{2}$. The mixture was fired for a long period of time at different oxygen pressures (to be denoted $\mathrm{PO}_{2}$ ) at $1000^{\circ} \mathrm{C}$ (for spinels) or $1200^{\circ} \mathrm{C}$ (for perovskites). $X$-ray powder diagrams and Mossbauer spectra were obtained from each specimen.

Results

a) Spinels: In the spinels studied, Co is situated in the T-sites (Tetrahedral anion coordination) with divalent oxidation state. The decay of ${ }^{57} \mathrm{Co}^{2+}(\mathrm{T})$ produces ${ }^{57} \mathrm{Fe}^{\mathrm{m} 2+}$ and ${ }^{57} \mathrm{Fe}^{\mathrm{m} 3+}$ in a ratio depending on the $\mathrm{PO}_{2}$ during the synthesis (Table I). b) Perovskites: The octaedral positions are occupled by $C o$ cations. It is assumed that the charge compensation of anion vacancies takes place according to $\mathrm{Ln}^{3+} \mathrm{Co}_{1-2 x}^{3+} \mathrm{Co}_{2 x}^{2+} \mathrm{O}_{3-x}$ ( $\mathrm{Ln}: \mathrm{Eu}, \mathrm{La}, \mathrm{Dy}, \mathrm{Y}$ ). The non-appearance of $\mathrm{Fe}^{4+}$ in the Mussbauer spectra in $\mathrm{La}^{3+57} \mathrm{Ca}^{3+} \mathrm{O}_{3}$ dopped with $\mathrm{Sr}^{2+}\left(\mathrm{Ca}^{2+}\right)$ led us to suppose that the charge compensation of $\mathrm{Sr}^{2+}\left(\mathrm{Ca}^{2+}\right)$ dopping agrees with $\mathrm{La}_{0.75}^{3+} \mathrm{Sr}_{0.25}^{2+}$ $\mathrm{Co}^{3+} \mathrm{O}_{2.875^{\circ}}$ Mussbauer spectra have been fitted with single line characteristics of ${ }^{57} \mathrm{Fe}^{2+}$ and ${ }^{57} \mathrm{Fe}^{3+}$. Their ratio depending on the $\mathrm{PO}_{2}$. The abnormal line's width agrees with the existence of intrinsic or non-intrinsic oxygen vacancies (Table I). For all perovskites synthesized at air pressure the $X$-ray diagrams have the desired single phase. Additional lines appear in the perovskites synthesized under low $\mathrm{PO}_{2}$ or with dopping of $\mathrm{Sr}^{2+}(2,4)$.

\begin{tabular}{|c|c|c|c|c|c|}
\hline Saynce & $\begin{array}{l}\mathrm{PO}_{2} \\
(\mathrm{a}=\mathrm{n})\end{array}$ & $\begin{array}{l}\mathrm{Fe}^{3+} \\
(\dot{x})\end{array}$ & 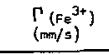 & $\begin{array}{l}\mathrm{Fe}^{2+} \\
(x)\end{array}$ & $\Gamma_{\mathrm{m} / \mathrm{s}}\left(\mathrm{Fe}^{2+}\right)$ \\
\hline $\mathrm{LACOO}$ & air & 100 & $0.47 \pm 0.04$ & & \\
\hline La co $\mathrm{O}_{3}$ : & air & 100 & $0.64 \pm 0.02$ & & \\
\hline$L=c_{0} O_{3}=s r$ & esir & 100 & $0.71 \pm 0.03$ & & \\
\hline \multirow[t]{2}{*}{ Dy $\approx 0_{3}$} & ad $r$ & 100 & $0.64 \div 0.03$ & & \\
\hline & $10^{-6}$ & 10 & $0.52 \pm 0.03$ & 90 & $0.51 \pm 0.03$ \\
\hline \multirow[t]{2}{*}{ Eu Co $\mathrm{O}_{3}$} & asr & 87 & $0.52 \pm 0.00$ & 13 & $0.38 \pm 0.1$ \\
\hline & $10^{-9}$ & 24 & $0.47 \pm 0.03$ & 76 & $0.38 \pm 0.06$ \\
\hline \multirow[t]{2}{*}{$Y \mathrm{CoO}_{3}$} & sir & 45 & $0.51 \pm 0.05$ & 55 & $0.64 \pm 0.05$ \\
\hline & $10^{-4}$ & 13 & $0 . \div 8 \pm 0.06$ & 87 & $0.67 \pm 0.06$ \\
\hline \multirow[t]{3}{*}{$\mathrm{SOAh}_{2} \mathrm{O}_{4}$} & asr & 100 & $0.47 \pm 0.01$ & & \\
\hline & $10^{-5}$ & 58 & $0.45 \pm 0.02$ & 42 & $0.4 \theta \pm 0.01$ \\
\hline & $10^{-8}$ & 47 & $0.42 \pm 0.02$ & 53 & $0.46 \pm 0.01$ \\
\hline \multirow[t]{3}{*}{$\alpha=\mathrm{H}_{2} \geq \mathrm{O}_{4}$} & air & 53 & $0.47 \pm 0.01$ & 47 & $0.45 \pm 0.02$ \\
\hline & $10^{-4}$ & 20 & $0.47 \pm 0.02$ & $\varepsilon_{0}$ & $0.43 \pm 0.03$ \\
\hline & 5. $10^{-9}$ & & & 100 & $0.40 \pm 0.05$ \\
\hline
\end{tabular}

Table I.Mussbauer parameters of the sources. The absorbent employed was $\mathrm{K}_{4} \mathrm{Fe}(\mathrm{CN} / 3 \mathrm{H} \mathrm{O}$ 
Discussion

In these axides the non-appearance of ${ }^{57} \mathrm{Fe}^{\mathrm{m} 4+}$ in the Mussbauer spectra means that ${ }^{57} \mathrm{Co}^{2+}$ originates at the most ${ }^{57} \mathrm{Fe}^{\mathrm{m} 3+}$ or ${ }^{57} \mathrm{Fe}^{\mathrm{m} 2+}$ and ${ }^{57} \mathrm{Co}^{3+}$ always gives ${ }^{57} \mathrm{Fe}^{\mathrm{m} 3+}$.

In spinels, samples prepared at different $\mathrm{PO}_{2}$, differ only in the cationic vacancy concentration, hence we conclude that the presence of such vacancies makes possible the ${ }^{57} \mathrm{Co}^{2+} \longrightarrow{ }^{57} \mathrm{Fe}{ }^{\mathrm{m} 3+\cdots}$ step with a probability depending on the vacancy concentration. The appearance of ${ }^{57} \mathrm{Fe}^{-\mathrm{m} 2+}$ in several perovskj.tes "prepared in air shows in these substances a lack of stoichiometry which increases with decreasing $\mathrm{PO}_{2}$.' The existerice of anionic (cationic) vacancies in the crystal is accompanied by the appearance of donor (acceptor) levels in the gap (5). The electric character of these levels is shown in Table II.

$\begin{array}{lll} & \text { Full } & \text { Empty } \\ \text { Donor. } & \text { Neutral } & \text { Positive } \\ \text { Acceptor } & \text { Negative } & \text { Neutral }\end{array}$

Table II. Charge state of the levels in term of their electron occupation.

The Auger electron cascade, produced after the electronic capture has taken place in the ${ }^{57}$ Co nucleus, gives rise to high charge states for the ${ }^{57} \mathrm{Fe}^{\mathrm{m}}$ daughter. This creates a strong oulombic field which allows one electron, at the most, To remain in the conduction band (C.8.). This electron can go into the levels created by vacancies; being the probability of this capture proportional to the concentration of those levels $\left(N_{T}\right)$ unocoupied by electrons $\left(N_{T}^{\prime}\right) . \quad N_{T}^{\prime}=N_{T}\left(1-f_{T}\right)$ where $f_{T}$ is the Femi-Dirac distribution function. This capture process can be described by $N_{T}^{\prime}{ }^{t}+e^{-} \rightarrow N_{T}^{\prime}$ g with a capture cross section $\sigma_{n}(6)$ depending bath on the electric character of the level and on its energy.

Two different processes could explain our results.

1) The donor (perovskites) and acceptor (spinels) levels are empty and they are acting as traps and recombination centers respectively. For donor levels the capture and pasterior, reemission to the C.B. takes a time less than $10^{-10} \mathrm{~s}$ tourning the electron to the emissor atom in the Mussbauer time scale. For acceptor levels, the time spend by the electron before tourning to the C.B. is orders of magnitud greater than $10^{-8} s$ making possible the appearance of ${ }^{57} \mathrm{Fe}^{\mathrm{m} 3+}$ in the Msssbauer spectra.

2) The acceptor levels are empty and the donor are full. In tris case only the cationic vacancies are able to capture the electron as in the precedent case.

We conclude that in spinels the amount of anomalous ${ }^{57} \mathrm{Fe}^{\mathrm{m} 3+}$ tells us about the desviations from stoichiometry. In perovskites the amount of ${ }^{57} \mathrm{Fe}^{3+}$ will be the same as that of ${ }^{57} \mathrm{Co}^{3+}$ hence in dicating the axide composition. From the Mossbauer results concerning to the perovskites prepared under low $\mathrm{PO}_{2}$ (see Table 1) and dopped can be conclude the non existence of a big variation in the surrounding of the $c 0$ atoms increasing the vacancy coricentration. For this reason the $X$-ray powder diagrams of those perovskites could be interpreted in terms of intermediate structures between perovs kite and brownmillerite.

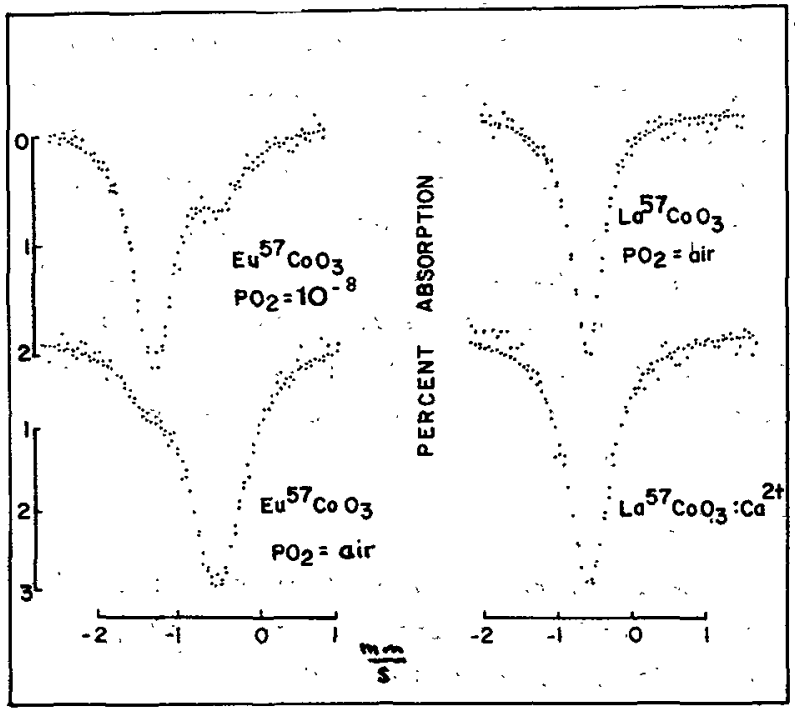

Fig. 1.MUssbauer spectra of some peroviskites:

1 DBAYASHI, H., HUDO; T., Mat. Res. BuII. 13, (1978) 1409-1413.

2 KAMATA, K., NAKAJIMA, T., HAYASHI, T., NAKAMURA, T., Mat. Res. Bull. 13 (1978) 49-54.

3 TEJADA, J., FONTCUBERTA, J., RODRIGUEZ R. J. Solid state Chem. 27, (1979) 329-341.

4 GRENIER, J.C., SCHIFFMACIER, G., CARO, P., POUCHAND, $M_{*}$, HAGENMULLER, P.; J. Solid State Chem. 20, (1977) 365-379.

5 JARZEBSKI, Z.M., "Oxide semiconductors", Val. 4, (B.R. Pamplin Ed.) Pergamon Press, Warszawa, 1973.

6 MILNES, A.G., "Deep-impurities in Semiconductors". John wiley, 1973. 